
УДК 611.08

DOI 10.11603/1811-2471.2020.v.i4.11758

\title{
ГІСТОМОРФОЛОГІЧНИЙ СТАН ОКА КРОЛЯ 3 МОДЕЛЬОВАНИМ ПЕРЕДНІМ І СЕРЕДНІМ НЕІНФЕКЦІЙНИМ УВЕЇТОМ ПРИ НОРМАЛІЗАЦІї ТЕМПЕРАТУРИ ОЧНОЇ ПОВЕРХНІ
}

\author{
๑О. Е. Дорохова, Е. В. Мальцев, О. В. Зборовська, М. Гуаньцзюнь
}

ДУ «Інститут очних хвороб і тканинної терапії імені В. П. Філатова НАМН України», Одеса

РЕЗЮмЕ. На сьогоднішній день вкрай важливим завданням є розробка об' єктивних методів оцінки внутрішньоочного запалення.

Мета - вивчити гістоморфологічний стан хворого ока кроля з модельованим неінфекційним переднім і середнім увеїтом при нормалізації температури очної поверхні в проекції циліарного тіла.

Матеріал і методи. Проведено вимірювання температури поверхні очей в проекції плоскої частини циліарного тіла на 17 кролях породи «шиншила» з модельованим неінфекційним переднім і середнім увеїтом. Також проведено гістоморфологічне дослідження очей 6 кролів.

Результати. Середній термін нормалізації температури дорівнює 46 дням (SD 8,8). У пізньому терміні експерименту циліарне тіло, як і райдужна оболонка, вже не мають ознак набряклості і не інфільтровані численними імунокомпетентними клітинами (переважно лімфо- і плазмоцитами), як це було в ранньому терміні спостереження. Структура склоподібного тіла, порівняно з раннім періодом спостереження, зазнала значних змін. Насамперед це виражалося різким зменшенням кількості клітин лімфоїдного ряду, які визначалися в ньому в попередньому терміні, хоча вони й залишалися. До того ж, посилювалися тинкторіальні властивості склоподібного тіла, що свідчить на користь його ущільнення. Щодо морфологічного стану оболонок стінки очного яблука, можна сказати, що власне судинна оболонка виглядає не зміненою. Таке явище, як утворення множинних тракцій сітківки в склоподібне тіло, - це нове патологічне утворення, яке не зустрічалося на попередньому, ранньому етапі експерименту. Головним у зміні гістологічної картини очних структур, порівняно з попереднім раннім терміном дослідження, $\epsilon$ стихання в них проявів активного запалення.

Висновки. Згідно з результатами гістоморфологічного дослідження, у кроля з модельованим неінфекційним переднім і середнім увеїтом нормалізація температури очної поверхні в проекції циліарного тіла відбувається в фазах проліферації та завершення запального процесу.

КлючовІ СловА: увеїт; об'єктивізація оцінки запалення; температура поверхні ока; гістоморфологічний стан.

Вступ. Увеїт є складним, потенційно загрозливим для зору внутрішньоочним запальним захворюванням, яке може бути викликане різними етіологічними чинниками [1-3]. Хоча увеїти належать до орфанних захворювань, вони займають четверте місце серед причин інвалідності за зором у країнах, що розвиваються [3-7].

Терміни клінічного й істинного одужання можуть не збігатися, що часто призводить до загибелі ока через млявий запальний процес, в більшості випадків не пролікований через відсутність діагностичних критеріїв його наявності. Тому важливим і маловивченим $є$ питання щодо термінів скасування протизапальної терапії при увеїтах [1]. Зміна ступеня активності процесу - важлива ознака, за якою оцінюється ефективність або неефективність терапії увеїту [8].

Єдина доступна на сьогоднішній день методика об'єктивного вимірювання ступеня запалення при увеїті - лазерна фотометрія. Вона ґрунтується на вимірах рівня білка і клітин у передній камері. Ця методика дозволяє виявити запальний процес навіть на субклінічному рівні й застосовується як для діагностики, так і для динамічного спостереження [9-13]. Але відсутність консенсусу щодо «клінічної користі» та неможливість виконання при недостат- ньому мідріазі й катаракті достатньо обмежують використання лазерної фотометрії $[14,15]$.

На сучасному етапі дуже важливим завданням $\epsilon$ розробка об'єктивних методів оцінки внутрішньоочного запалення за допомогою простих, дешевих і надійних методів, оскільки від цього залежить не тільки тактика лікування конкретного пацієнта, айоцінка результатів клінічнихвипробувань і розробка клінічних настанов і протоколів. Економічними, неінвазивними можна визнати методики обстежень з вимірювання локальної температури, які не мають протипоказань. Ці методики прості, інформативні та повністю безпечні для хворих навіть при багаторазових повтореннях [16]. Раніше завдяки розробленій нами методиці вимірювання температури очної поверхні нам вдалося встановити, що у кроля з модельованим неінфекційним переднім і середнім увеїтом при зникненні ознак активного переднього увеїту на фоні збереження підвищеної температури очної поверхні, визначаються ознаки активного середнього увеїту, причому циліарне тіло знаходиться в ексудативно-еміграційній фазі запалення [17].

Мета - вивчити гістоморфологічний стан хворого ока кроля з модельованим неінфекційним переднім і середнім увеїтом при нормалізації 
Огляди літератури, оригінальні дослідження, погляд на проблему, випадок з практики, короткі повідомлення температури очної поверхні в проекції циліарного тіла.

Матеріал і методи дослідження. Експеримент проведено на 17 кролях породи «шиншила» (34 ока) вагою від 2,5 до 3 кг. Кролів було поділено на 2 серії експерименту: в одній -7 кролів, у другій - 10 кролів. До проведення досліджень тварини перебували на карантині протягом двох тижнів. Кролів утримували в стандартних умовах віварію, на стандартних раціоні харчування і водному режимі. Температура приміщення становила від 18 до $25^{\circ} \mathrm{C}$. Експеримент проводили з дотриманням етичних норм, передбачених міжнародними принципами Європейської конвенції «Про захист хребетних тварин, які використовуються для експериментів та інших наукових цілей» (Страсбург, 1985) та норм біомедичної етики, схвалених Першим Національным конгресом України з біоетики (2001), а також згідно з Законом України № 3447-IV «Про захист тварин від жорстокого поводження» (Київ, 2006). Проведення дослідження було схвалено біоетичним комітетом ДУ «Інститут очних хвороб і тканинної терапії імені В. П. Філатова НАМН України».

Всім кролям моделювали неінфекційний передній та середній увеїт на правих очах, ліві очі контрлатеральні (парні) були здорові. Методику моделювання увеїту описано в нашій попередній роботі [18].

Перебіг запального процесу контролювали за допомогою біомікроскопії, офтальмоскопії, термометрії поверхні ока в проекції циліарного тіла, оцінки ступеня запальної реакції за розробленою бальною системою критеріїв. Усім тваринам проводили вимірювання температури поверхні ока в проекції циліарного тіла за методикою, описаною в нашій попередній роботі [19]. Для вимірювання температури поверхні очей експериментальних тварин використовували термоелектричний пристрій, розроблений в Інституті термоелектрики НАН і МОН України в рамках договору про співпрацю 3 ДУ «Інститут очних Хвороб і тканинної терапії імені В. П. Філатова НАМН України» [20]. Кожному кролю вимірювання проводили через день або через 2 дні в першій серії, і через 4-6 днів у другій серії.

Термін спостереження склав від 6 до 57 днів. Було сформовано дві групи виведення тварин 3 експерименту. Перша - рання група виведення виведення тварин здійснювалося при офтальмоскопічному зникненні клінічних симптомів активного увеїту (строк біля 1-2 тижнів). Друга група - пізня група виведення - виведення тварин здійснювалося при нормалізації температури хворого ока відносно парного ока (в послідовні дні вимірювання різниця між хворим і парним оком не перевищувала $\left.0,2^{\circ} \mathrm{C}\right)$. У міру виведення

тварин з експерименту у кролів забирали очні яблука для виконання гістоморфологічних досліджень. В цій статті наведені результати гістоморфологічного дослідження очей кролів другої групи. Результати гістоморфорлогічних досліджень кролів першої групи наведені в попередній статті, з якими проводиться порівняння [17].

Тварин виводили з досліду шляхом повітряної емболії після попереднього введення тіопенталу натрію в дозі 50 мг/кг. Після забою тварин енуклейовані очі для світлооптичного гістоморфологічного дослідження фіксували в $10 \%$ нейтральному формаліні, а потім заливали в парафін. Виготовлені зрізи товщиною 5 мкм забарвлювали гематоксиліном - еозином.

Проведено гістоморфологічне дослідження очей 6 кролів, у яких відзначалася нормалізація температури хворого ока відносно парного ока (в послідовні дні вимірювання різниця між хворим і парним оком не перевищувала $0,2{ }^{\circ} \mathrm{C}$ ). Всі гістоморфологічні дослідження проводили на базі лабораторії патоморфологічних і електронномікроскопічних досліджень ДУ «Інститут очних хвороб і тканинної терапії імені В. П. Філатова НАМН України». Мікрофотографування препаратів проводили на мікроскопі «Laboval 4, Carl Zeiss, Jena» на цифрову фотокамеру «Canon PowerShot A480» при зазначених в підписах до рисунків збільшеннях.

Результати й обговорення. В групу пізнього виведення було включено 8 кролів (відібрано $з$ двох серій експерименту). У першого кроля нормалізація температури хворого ока відносно контрольного відбулася на 34 , у трьох на 40 , по одному кролю на 44 та 55, та у двох - на 57 добу. Середній день нормалізації температури склав 46 днів (SD 8,8).

У пізньому терміні експерименту циліарне тіло, як і райдужна оболонка, вже не мали ознак набряклості й не були інфільтровані численними імунокомпетентними клітинами (переважно лімфо- і плазмоцитами), як це мало місце на ранньому терміні спостереження. Це підтверджується мікрофотографіями названих структур переднього відділу ока (рис. 1, 2).

Структура склоподібного тіла, порівняно 3 раннім періодом спостереження, зазнала значних змін. Насамперед це виражалося різким зменшенням кількості клітин лімфоїдного ряду, які розташовувалися в ньому в попередньому терміні, хоча вони і виявлялися. До того ж, посилювалися тинкторіальні властивості склоподібного тіла, що свідчить на користь його ущільнення (рис. 3). На рисунку 3 наведено ділянку організації наявного в склоподібному тілі запального процесу на 44 добу експерименту. Цей знімок зроблений неподалік від головки зорового нерва, що знаходиться за 
Огляди літератури, оригінальні дослідження, погляд на проблему, випадок з практики, короткі повідомлення межами кадру. У його правій частині розташовуються витягнуті клітини з такими ж ядрами і новоутворені волокна. Інші клітини, розташовані поблизу, представлені макрофагами, лімфоцитами, плазмоцитами і навіть еритроцитами. Загальна

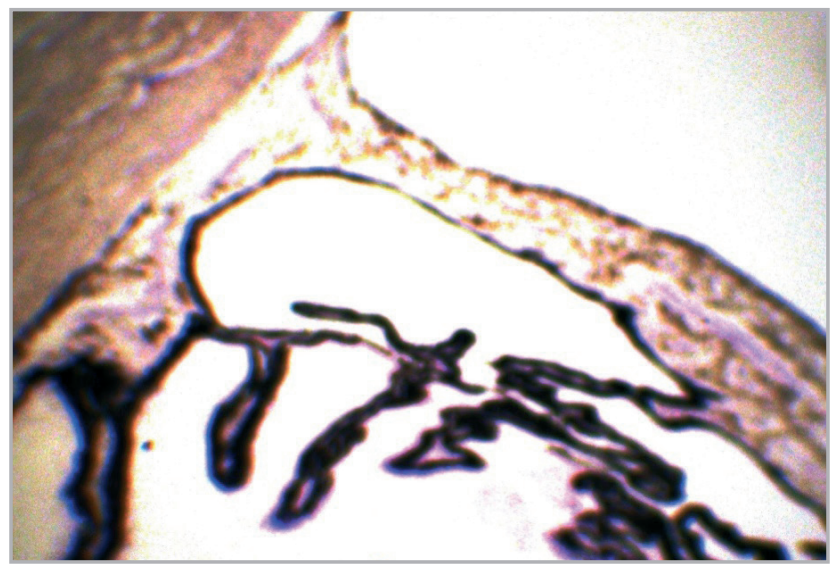

Рис. 1. Хворе око, 40 доба. Циліарне тіло і райдужка нормальної будови. Фарбування гематоксиліном еозином. 06. 3,2. Ок. 7.

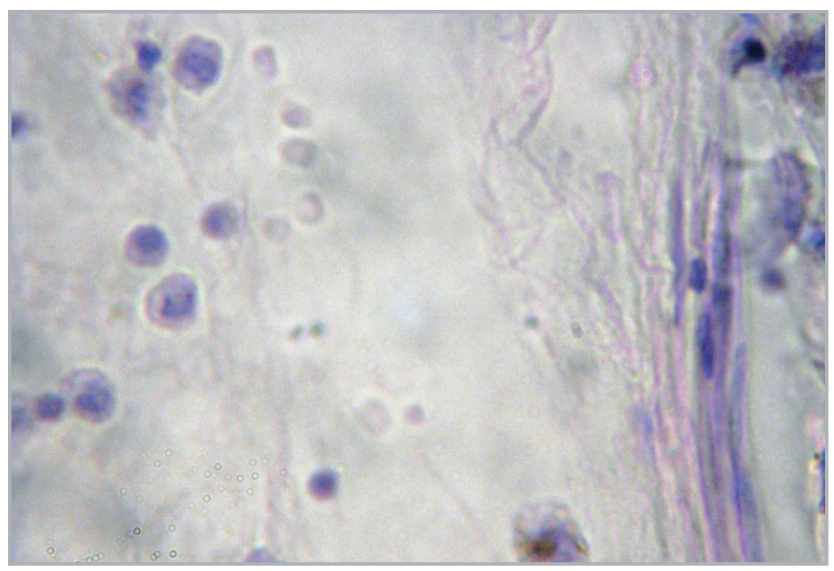

Рис. 3. Хворе око. 44 доба. По периферії організації запального процесу поблизу головки зорового нерва в кадрі праворуч розташовуються клітини з витягнутими ядрами і волокна. Інші клітини представлені макрофагами, лімфоцитами, плазмоцитами. Фарбування гематоксиліном - еозином. О6. 40. Ок. 16.

На рисунку 4 також видно, що ширина описаної тут тканини може наближатися навіть до загальної товщини стінки очного яблука. Крім вже описаної особливості тканини, що утворилася в склоподібному тілі, слід вказати на можливість появи в ній ще одного цікавого утворення. Йдеться про відносно щільний клітинний тяж, який простягнувся від плоскої частини циліарного тіла, поступово звужуючись, углиб склоподібного тіла (рис. 5).

Щодо морфологічного стану оболонок стінки очного яблука, можна сказати, що власне судинна оболонка виглядає не зміненою (не кажучи вже структура такої тканини, що утворилася в склоподібному тілі, в місцях де раніше були масивні скупчення імунокомпетентних клітин (що було описано в ранньому терміні спостереження), показана на рисунку 4.

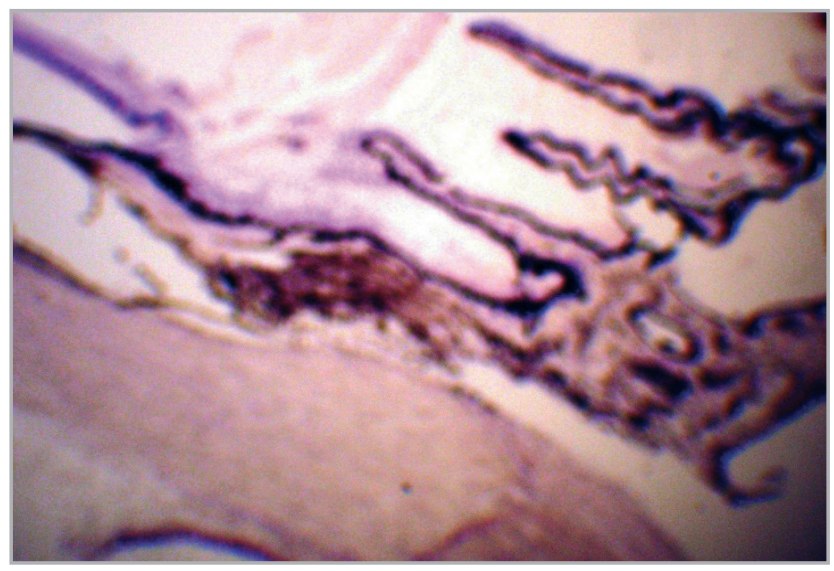

Рис. 2. Хворе око, 40 доба. Циліарне тіло без ознак набряку та клітинної інфільтрації. Фарбування гематоксиліном-еозином. О6. 3,2. Ок. 7.

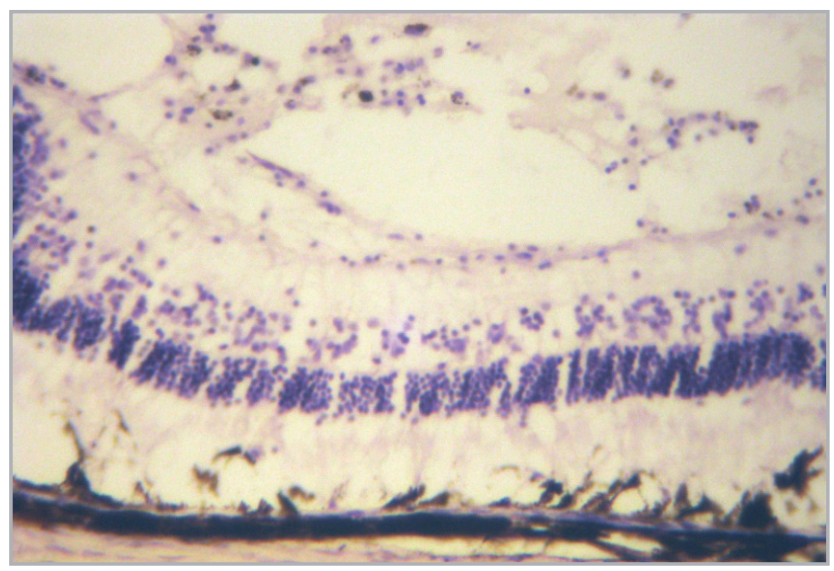

Рис. 4. Хворе око, 40 доба. Клітинно-волокниста тканина в склоподібному тілі, що контактує з сітківкою. Фарбування гематоксиліном - еозином. Об. 10. Ок. 16.

про склеру). Це добре помітно на рисунку 6. До речі, на цьому ж рисунку і структура сітківки практично не порушена, що має місце далеко не скрізь.

Утворення множинних тракцій сітківки в склоподібне тіло - це нове патологічне утворення, яке не зустрічалося на попередньому, ранньому етапі експерименту (рис. 7). На рисунку 7 добре видно новоутворену тканину в склоподібному тілі, до якої підтягнута сітківка.

Головним у зміні гістологічної картини очних структур, порівняно з попереднім, раннім термі- 


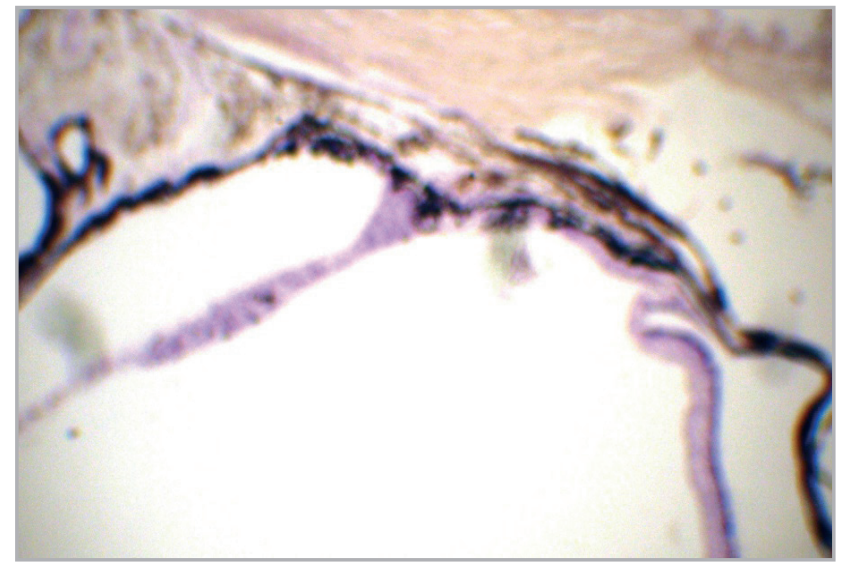

Рис. 5. Хворе око, 44 доба. Клітинний тяж, що тягнеться від плоскої частини циліарного тіла вглиб склоподібного тіла. Фарбування гематоксиліном еозином. О6. 3,2. Ок. 7.

ном дослідження, $є$ стихання в них проявів активного запалення. Зникнення запалення в циліарному тілі виражається практично повним зникненням його набряклості й інфільтрації імунокомпетентними клітинами - плазмоцитами, макрофагами і різними представниками лімфоцитарного ряду. Однак невелика кількість таких клітин ще знаходиться в склоподібному тілі, тинкторіальні властивості якого трохи посилюються. Крім того, в ньому з'являються осередки організації у вигляді клітинно-волокнистої тканини, представлені клітинами з витягнутими ядрами і волокнами. Невелика кількість інших клітин тут представлена макрофагами, лімфоцитами, плазмоцитами.

Завдяки гістоморфологічному дослідженню нам вдалося зіставити о6' єктивний стан внутрішньоочного запалення з температурою поверхні ока. Нормалізація температури поверхні хворого ока в проекції циліарного тіла у кролів з модельованим неінфекційним переднім і середнім увеїтом відбувається в фазах проліферації та завершення запального процесу, згідно з критеріями запалення [21].

У статті Chen J. зі співавторами, опублікованій в 2019 році, підкреслюється, що для кращого використання моделей аутоімунних увеїтів, крім суб' єктивної оцінки їх перебігу, необхідні точні й зручні методи об' єктивної динамічної оцінки процесу, що розвивається. При цьому вони повинні бути неінвазивними, щоб не впливати на розвиток і прогресування модельованого захворювання. Автори пропонують такі неінвазивні клінічні методики як фотографування, оптичну когерентну томографію і функціональну оцінку за допомогою електроретинографії, які потім порівнюються з гістологічними даними. Було показано, що клінічні варіанти захворювання можуть бути точно оцінені як клінічно, так і функціонально, що по-

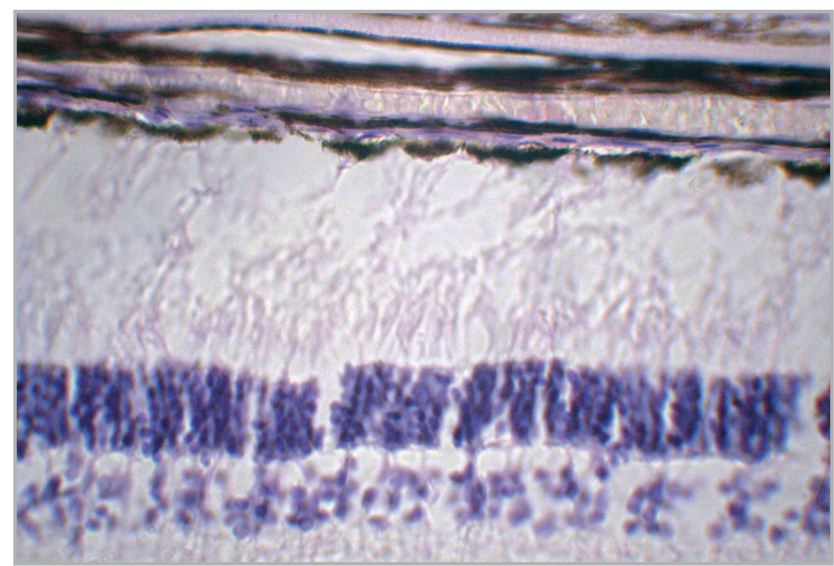

Рис. 6. Хворе око, 40 доба. Оболонки ока зберегли нормальну будову. Фарбування гематоксиліном еозином. О6. 10. Ок. 7.

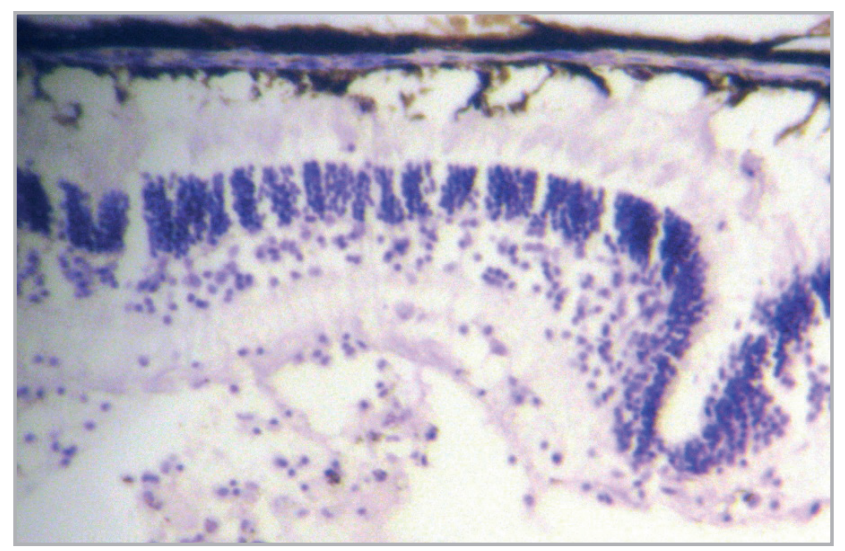

Рис. 7. Хворе око, 40 доба. Клітинно-волокниста тканина в склоподібному тілі, що контактує з сітківкою. Фарбування гематоксиліном - еозином. О6. 10. Ок. 16.

легшує динамічне спостереження і надає інформацію, яку неможливо одержати тільки за допомогою фундоскопії та гістології [22]. Ще одним методом, запропонованим нами з тією ж метою, $\epsilon$ дослідження температури поверхні ока в проекції циліарного тіла. Результати його ніяк не впливають на перебіг досліджуваного процесу, а значить цей метод повністю відповідає коректним умовам оцінки перебігу експериментальних увеїтів. Важливо й те, що цей метод простий у виконанні і його застосування не потребує відтворення складних умов проведення дослідження чи спеціальних навиків.

При увеїтах, асоційованих із системними захворюваннями, їх активність відображає загальну компенсацію захворювання, тому потрібен регулярний моніторинг активності запального процесу для своєчасного прийняття рішення про зміну системної терапії. Контроль запалення в передній камері за допомогою лазерної фотометрії - набагато чутливіший метод, що має об'єктивний кіль- 
Огляди літератури, оригінальні дослідження, погляд на кісний характер, на відміну від загальноприйнятого «підрахунку клітин» у передній камері [23]. Методика вимірювання температури очної поверхні в проекції циліарного тіла при увеїтах може становити величезну цінність, особливо в тих випадках, коли візуалізація склоподібного тіла утруднена. Наприклад, хоча розвиток середнього увеїту зустрічається рідше, ніж переднього, у пацієнтів, позитивних за HLA-B27 антигеном, діагностика саме середнього увеїту може бути утруднена через часті ускладнення переднього увеїту у вигляді задніх синехій і катаракти [24]. В такому випадку оцінити наявність / активність як переднього, так і середнього увеїту за допомогою єдиного наявного на сьогодні методу об'єктивної оцінки рівня внутрішньоочного запалення - лазерної фотометрії неможливо через технічні характеристики приладу $[25,26]$. До того ж, обладнання, необхідне для виконання лазерної фотометрії, не розповсюджене через високу його вартість. Подібна ситуація, коли неможливо оцінити активність запалення, може скластися й при інших тяжких увеїтах, таких як увеїт, асоційований з ювенільним ідіопатичним артритом, увеїт при хворобі Бехчета і при синдро-

\section{ЛІТЕРАТУРА}

1. Бакбардина Л. М. Термометрическая диагностика воспалитльного процесса переднего отделения увеального тракта : автореф. дисс. на соискание уч. степени канд. мед. наук: спец. 14.00.08. «Глазные болезни» / Л. М. Бакбардина. - Одесса, 1988. - 15 с.

2. Еременко А. Ю. Термография в диагностике сосудистых невритов зрительного нерва / А. Ю. Еременко // Офтальмологический журнал. - 1990. - № 4. C. 235-239.

3. Chronic severe uveitis: etiology and visual outcome in 927 patients from a single center / B. Bodaghi, N. Cassoux, B. Wechsler [et al.] // Medicine (Baltimore). - 2001. Vol. 80 (4). - P. 263-270.

4. Incidence and prevalence of uveitis: results from the Pacific Ocular Inflammation Study / N. R. Acharya, V. M. Tham, E. Esterberg [et al.] // JAMA Ophthalmology. 2013. - Vol. 131 (11). - P. 1405-1412.

5. Nussenblatt R. B. The natural history of uveitis / R. B. Nussenblatt // Int. Ophthalmol. - 1990. - Vol. 14 (5-6). P. 303-308.

6. Suttorp-Schulten M. S. The possible impact of uveitis in blindness: a literature survey / M. S. Suttorp-Schulten, A. Rothova // Br. J. Ophthalmol. - 1996. - Vol. 80 (9). P. 844-848.

7. Uveitis-a rare disease often associated with systemic diseases and infections-a systematic review of 2619 patients / T. Barisani-Asenbauer, S. M. Maca, L. Mejdoubi [et al.] // Orphanet J. Rare Dis. - 2012. - Vol. 7 (1). - P. 1-7.

8. Interobserver agreement in grading activity and site of inflammation in eyes of patients with uveitis / ому, випадок з практики, короткі повідомлення мі Фогта - Каянагі-Харада, через розвиток ускладнень, які зазначені вище. А у випадку з ювенільним ідіопатичним артритом до них додається і частий розвиток стрічкоподібної дистрофії рогівки [27]. У подібних випадках розроблена нами методика термометрії $\epsilon$ єдиною, яка дозволить об' єктивно оцінити наявність / активність середнього увеїту, i, відповідно, за необхідності провести корекцію терапії. Ця методика відповідає вимогам щодо методів in vivo, бо є безпечною для пацієнтів і не впливає на перебіг захворювання.

Висновок. Згідно з результатами гістоморфологічного дослідження, у кроля з модельованим неінфекційним переднім і середнім увеїтом нормалізація температури очної поверхні в проекції циліарного тіла відбувається в фазу проліферації та завершеня запального процесу.

Перспективи подальших досліджень. В нашій подальшій роботі ми плануємо перейти до клінічних випробувань методики вимірювання температури очної поверхні у пацієнтів з неінфекційними передніми та середніми увеїтами, оскільки в експерименті було продемонстровано велику точність та клінічну цінність цього методу.

J. H. Kempen, S. K. Ganesh, V. S. Sangwan, S. R. Rathinam // Am. J. Ophthalmol. - 2008. - Vol. 146 (6). - P. 813-818.

9. Астахов Ю. С. Значение лазерной фотометрии в клинической практике / Ю. С. Астахов, Т. Ю. Кузнецова // Офтальмологические ведомости. - 2016. - № 9 (2). С. 36-44.

10. Guney E. Symptoms and Signs of Anterior Uveitis / E. Guney, I. Tugal-Tutkun // US Ophthalmic Review. 2013. - Vol. 6 (1). - P. 33-37.

11. Use of laser flare photometry to assess and monitor inflammation in uveitis / C. P. Herbort, Y. Guex-Crosier, E. de Ancos, N. Pittet// Ophthalmol. -1997. - Vol. 104 (1). P. 64-72.

12. Laser flare-cell photometry: methodology and clinical applications / J. G. Ladas, N. C. Wheeler, P. J. Morhun [et al.] // Surv. Ophthalmol. - 2005. - Vol. 50 (1). - P. 27-47.

13. Tugal-Tutkun I. Laser flare photometry: a noninvasive, objective, and quantitative method to measure intraocular inflammation / I. Tugal-Tutkun, C. P. Herbort // Int. Ophthalmol. - 2010. - Vol. 30 (5). - P. 453-464.

14. Relationships between laser flare photometry values and complications of uveitis / C. A. Gonzales, J. G. Ladas, J. L. Davis [et al.] // Arch. Ophthalmol. - 2001. - Vol. 119 (12). P. $1763-1769$.

15. Discrepancies in assessing anterior chamber activity among uveitis specialists / T. H. Yeo, S. Ilangovan, P. A. Keane [et al.] // Jpn. J. Ophthalmol. - 2016. - Vol. 60 (3). P. 206-211.

16. Risk of ocular complications in patients with noninfectious intermediate uveitis, posterior uveitis, or panu- 
Огляди літератури, оригінальні дослідження, погляд на проблему, випадок з практики, короткі повідомлення veitis / A. D. Dick, N. Tundia, R. Sorg [et al.] // Ophthalmol. 2016. - Vol. 123 (3). - P. 655-662.

17. Гистоморфологическое состояние глаза кролика с моделированным передним и средним неинфекционным увеитом при отсутствии его клинических признаков, но повышенной температурой глазной поверхности / А. Э. Дорохова, Э. В. Мальцев, А. В. 36оровская, Мен Гуаньцзюнь // Офтальмология. Восточная Европа. 2020. (Препринт).

18. Dorokhova O. Changes in temperature of the ocular surface in the projection of the ciliary body in the early stages of induced non-infectious uveitis in rabbits / O. Dorokhova, O. Zborovska, M. Guanjun // J. Ophthalmol. - 2020. - Vol. 494 (3). - P. 47-52. - Access mode : http://www.ozhurnal.com/en/archive/2020/3/ 9-fulltext.

19. Dorokhova O. Temperature of the ocular surface in the projection of the ciliary body in rabbits / O. Dorokhova, O. Zborovska, M. Guanjun // J. Ophthalmol. - 2020. Vol. 493 (2). - P. 65-69. - Access mode : http://www.ozhurnal.com/sites/default/files/2020-2-11.pdf.

20. Original device and approaches to the study of temperature distribution in various eye segments (experimental study) / L. Anatychuk, N. Pasyechnikova, O. Zadorozhnyy [et al.] // J. Ophthalmol. - 2015. - Vol. 6. - P. 50-53. Access mode : http://www.ozhurnal.com/en/archive/2015/ 6/11-fulltext.

\section{REFERENCES}

1. Bakbardyna, L.M. (1988). Termometricheskaya diagnostika vospalitlnogo protsessa perednego otdeleniya uvealnogo trakta [Thermometric diagnostika of the inflammatory process of the anterior section of the uveal tract]. Extended abstract of Candidate's thesis. Odesa [in Russian].

2. Yeremenko, A.Yu. (1990). Termografiya v diagnostike sosudistykh nevrytov zritelnogo nerva [Thermography in the diagnosis of vascular neuritis of the optic nerve]. Oftalmologicheskiy zhurnal - Ophthalmological Journal, 4, 235-239 [in Russian].

3. Bodaghi, B., Cassoux, N., Wechsler, B., Hannouche, D., Fardeau, C., Papo, T., ..., \& LeHoang, P. (2001). Chronic severe uveitis: etiology and visual outcome in 927 patients from a single center. Medicine (Baltimore), 80 (4), 263-270.

4. Acharya, N.R., Tham, V.M., Esterberg, E., Borkar, D.S., Parker, J.V., Vinoya, A.C., \& Uchida, A. (2013). Incidence and prevalence of uveitis: results from the Pacific Ocular Inflammation Study. JAMA Ophthalmol., 131 (11), 1405-1412.

5. Nussenblatt, R.B. (1990). The natural history of uveitis. Int. Ophthalmol., 14 (5-6), 303-308.

6. Suttorp-Schulten, M.S., \& Rothova, A. (1996). The possible impact of uveitis in blindness: a literature survey. Br. J. Ophthalmol., 80 (9), 844-848.

7. Barisani-Asenbauer, T., Maca, S.M., Mejdoubi, L., Emminger, W., Machold, K., \& Auer, H. (2012). Uveitis-a rare disease often associated with systemic diseases and infections-a systematic review of 2619 patients. Orphanet J. Rare Dis., 7 (1), 1-7.

21. Зайко Н. Н. Патологическая физиология / Н. Н. Зайко, Ю. В. Быць. - М.: МЕДпресс-информ, 2004. C. 194-221.

22. Chen J. Clinical and functional evaluation of ocular inflammatory disease using the model of experimental autoimmune uveitis / J. Chen, R. R. Caspi // In: Immunological Tolerance. - New York, NY.: Humana Press, 2019. P. 211-227.

23. Bernasconi O. Sensitivity of laser flare photometry compared to slit-lamp cell evaluation in monitoring anterior chamber inflammation in uveitis / O. Bernasconi, M. Papadia, C. P. Herbort // Int. Ophthalmol. - 2010. Vol. 30 (5). - P. 495-500.

24. Clinical spectrum of HLA-B27-associated ocular inflammation / K. Pathanapitoon, E. M. Dodds, E. T. Cunningham Jr, A. Rothova // Ocul. Immunol. Inflamm. - 2017. Vol. 25 (4). - P. 569-576.

25. Relationships between laser flare photometry values and complications of uveitis / C. A. Gonzales, J. G. Ladas, J. L. Davis [et al.] // Arch. Ophthalmol. - 2001. - Vol. 119 (12). - P. 1763-1769.

26. Discrepancies in assessing anterior chamber activity among uveitis specialists / T. H. Yeo, S. Ilangovan, P. A. Keane [et al.] // Jpn. J. Ophthalmol. -2016. - Vol. 60 (3). - P. 206-211.

27. Qian Y. Juvenile idiopathic arthritis associated uveitis / Y. Qian, N. R. Acharya // Curr. Opin. Ophthalmol. 2010. - Vol. 21 (6). - P. 468.

8. Kempen, J.H., Ganesh, S.K., Sangwan, V.S., \& Rathinam, S.R. (2008). Interobserver agreement in grading activity and site of inflammation in eyes of patients with uveitis. Am. J. Ophthalmol., 146 (6), 813-818.

9. Astaxov, Yu.S., \& Kuzneczova, T.Y. (2016). Znachenye lazernoi fotometrii v klinicheskoy pryaktike [The values of laser photometers in the clinical interface]. Oftalmologycheskye vedomosty - Ophthalmological News, 9 (2), 36-44 [in Russian].

10. Guney, E., \& Tugal-Tutkun, I. (2013). Symptoms and signs of anterior uveitis. US Ophthalmic Review, 6 (1), 33-37.

11. Herbort, C.P., Guex-Crosier, Y., de Ancos, E., \& Pittet, N. (1997). Use of laser flare photometry to assess and monitor inflammation in uveitis. Ophthalmol., 104 (1), 64-72.

12. Ladas, J.G., Wheeler, N.C., Morhun, P.J., Rimmer, S.O., \& Holland, G.N. (2005). Laser flare-cell photometry: methodology and clinical applications. Surv. Ophthalmol., 50 (1), 27-47.

13. Tugal-Tutkun, I., \& Herbort, C.P. (2010). Laser flare photometry: a noninvasive, objective, and quantitative method to measure intraocular inflammation. Int. Ophthalmol., 30 (5), 453-464.

14. Gonzales, C.A., Ladas, J.G., Davis, J.L., Feuer, W.J., \& Holland, G.N. (2001). Relationships between laser flare photometry values and complications of uveitis. Arch. Ophthalmol., 119 (12), 1763-1769.

15. Yeo, T.H., Ilangovan, S., Keane, P.A., Pavesio, C., \& Agrawal, R. (2016). Discrepancies in assessing anterior chamber activity among uveitis specialists. Jpn. J. Ophthalmol., 60 (3), 206-211. 
Огляди літератури, оригінальні дослідження, погляд на проблему, випадок з практики, короткі повідомлення

16. Dick, A.D., Tundia, N., Sorg, R., Zhao, C., Chao, J., Joshi, A., \& Skup, M. (2016). Risk of ocular complications in patients with noninfectious intermediate uveitis, posterior uveitis, or panuveitis. Ophthalmol., 123 (3), 655-662.

17. Dorokhova, A.E., Maltsev, E.V., Zborovskaya, A.V., \& Guanjun, M. (2020). Gistomorfologicheskoye sostoyaniye glaza krolika s modelirovannym perednim i srednim neinfektsionnym uveitom pri otsutstvii yego klinicheskikh priznakov, no povyshennoy temperaturoy glaznoy poverkhnosti [The histomorphological state of a rabbit's eye with simulated anterior and middle non-infectious uveitis in the absence of its clinical signs, but with an increased temperature of the ocular surface]. Oftalmologiya. Vostochnaya Yevropa-Ophthalmology Eastern Europe, [in Russian].

18. Dorokhova, O., Zborovska, O., \& Guanjun, M. (2020). Changes in temperature of the ocular surface in the projection of the ciliary body in the early stages of induced noninfectious uveitis in rabbits. J. Ophthalmol., 494 (3), 47-52. Retrieved from: http://www.ozhurnal.com/en/archive/ 2020/3/9-fulltext.

19. Dorokhova, O., Zborovska, O., \& Guanjun, M. (2020). Temperature of the ocular surface in the projection of the ciliary body in rabbits. J. Ophthalmol., 493 (2), 65-69. Retrieved from: http://www.ozhurnal.com/sites/default/ files/2020-2-11.pdf.

20. Anatychuk, L., Pasyechnikova, N., Zadorozhnyy, O., Nazaretian, R., Myrnenko, V., Kobylyanskyi, R., \& Gavrilyuk N. (2015). Original device and approaches to the study of tem- perature distribution in various eye segments (experimental study). J. Ophthalmol., 6, 50-53. Retrieved from: http:// www.ozhurnal.com/en/archive/2015/6/11-fulltext.

21. Zaiko, N.N., \& Bic, J.V. (2004). Patologicheskaya fiziologiya [Pathological physiology]. Moscow: "MEDpressinform" [in Russian].

22. Chen, J., \& Caspi, R.R. (2019). Clinical and functional evaluation of ocular inflammatory disease using the model of experimental autoimmune uveitis. In: Immunological Tolerance. New York, NY.: Humana Press.

23. Bernasconi, O., Papadia, M., \& Herbort, C.P. (2010). Sensitivity of laser flare photometry compared to slit-lamp cell evaluation in monitoring anterior chamber inflammation in uveitis. Int. Ophthalmol., 30 (5), 495-500.

24. Pathanapitoon, K., Dodds, E.M., Cunningham Jr, E.T., \& Rothova, A. (2017). Clinical spectrum of HLA-B27-associated ocular inflammation. Ocul. Immunol. Inflamm., 25 (4), 569-576.

25. Gonzales, C.A., Ladas, J.G., Davis, J.L., Feuer, W.J., \& Holland, G.N. (2001). Relationships between laser flare photometry values and complications of uveitis. Arch. Ophthalmol., 119 (12), 1763-1769.

26. Yeo, T.H., Ilangovan, S., Keane, P.A., Pavesio, C., \& Agrawal, R. (2016). Discrepancies in assessing anterior chamber activity among uveitis specialists. Jpn. J. Ophthalmol., 60 (3), 206-211.

27. Qian, Y., \& Acharya, N.R. (2010). Juvenile idiopathic arthritis associated uveitis. Curr. Opin. Ophthalmol., 21 (6), 468.

\section{ГИСТОМОРФОЛОГИЧЕСКОЕ СОСТОЯНИЕ ГЛАЗА КРОЛИКА С МОДЕЛИРОВАННЫМ ПЕРЕДНИМ И СРЕДНИМ НЕИНФЕКЦИОННЫМ УВЕИТОМ ПРИ НОРМАЛИЗАЦИИ ТЕМПЕРАТУРЫ ГЛАЗНОЙ ПОВЕРХНОСТИ}

\section{๑А. Э. Дорохова, Э. В. Мальцев, А. В. Зборовская, М. Гуаньцзюнь}

ГУ «Институт глазных болезней и тканевой терапии имени В. П. Филатова НАМН Украины», Одесса

РЕЗЮМЕ. На сегодняшний день крайне важной задачей является разработка объективных методов оценки внутриглазного воспаления.

Цель - изучить гистоморфологическое состояние больного глаза кролика с моделированным неинфекционным передним и средним увеитом при нормализации температуры глазной поверхности в проекции цилиарного тела.

Материал и методы. Проведено измерение температуры поверхности глаз в проекции плоской части цилиарного тела на 17 кроликах породы «шиншилла» с моделированным неинфекционным передним и средним увеитом. Также проведено гистоморфологическое исследование глаз 6 кроликов.

Результаты. Средний срок нормализации температуры равнялся 46 дням (SD 8,8). В позднем сроке эксперимента цилиарное тело, как и радужная оболочка, уже не имеют признаков отечности и не инфильтрированны многочисленными иммунокомпетентными клетками (преимущественно лимфо- и плазмоцитами), как это имело место на раннем сроке наблюдения. Структура стекловидного тела, по сравнению с ранним периодом наблюдения, претерпела значительные изменения. Прежде всего, это выражалось резким уменьшением количества клеток лимфоидного ряда, которые располагались в нем в предыдущем сроке, хотя они и присутствовали. К тому же, усиливались тинкториальные свойства стекловидного тела, что свидетельствовало в пользу его уплотнения. Относительно морфологического состояния оболочек стенки глазного яблока, можно сказать, что собственно сосудистая оболочка выглядит не измененной. Такое явление, как образование множественных тракций сетчатки в стекловидное тело, - это новое патологическое образование, которое не встречалось на предыдущем, раннем этапе эксперимента. Главное в изменении гистологической картины глазных структур, по сравнению с предыдущим, ранним сроком исследования, является стихание в них проявлений активного воспаления.

Выводы. Согласно результатам гистоморфологического исследования, у кролика с моделируемым неинфекционным передним и средним увеитом нормализация температуры глазной поверхности в проекции цилиарного тела происходит в фазы пролиферации и завершения воспалительного процесса.

КЛЮЧЕВЫЕ СЛОВА: увеит; объективизация оценки воспаления; температура поверхности глаза; гистоморфологическое состояние. 
Огляди літератури, оригінальні дослідження, погляд на проблему, випадок з практики, короткі повідомлення

\title{
HISTMORPHOLOGICAL CONDITION OF RABBIT EYE WITH INDUCED ANTERIOR AND INTERMEDIATE NON-INFECTIOUS UVEITIS WITH NORMALIZATION OF THE OCULAR SURFACE TEMPERATURE
}

\author{
@O. E. Dorokhova, E. V. Maltsev, O. V. Zborovska, M. Guanjun
}

Filatov Institute of Eye Diseases and Tissue Therapy of the National Academy of Medical Sciences of Ukraine, Odesa

SUMMARY. Today it's extremely important to develop objective methods for assessing intraocular inflammation.

The aim of the study - to learn the histomorphology of rabbit eye with induced non-infectious anterior and intermediate uveitis with normalization of the ocular surface temperature.

Material and Methods. The temperature of the ocular surface in the projection of the ciliary body pars plana was measured on 17 chinchilla rabbits with induced non-infectious anterior and intermediate uveitis. The histomorphological examination of 6 rabbits' eyes was carried out.

Results and Discussion. The average day of temperature normalization is 46 days (SD 8.8). In the late period of the experiment, the ciliary body, like the iris, no longer exhibits signs of edema and is not infiltrated by numerous immunocompetent cells (mainly lymphocytes and plasmocytes), as we observed at the early period. Regarding the vitreous body, its structure has undergone significant changes in comparison with the early observation period. First of all, this is expressed by a sharp decrease in the number of cells of the lymphoid series, which were located in it in the previous period. In addition, the tinctorial properties of the vitreous are enhanced, which indicates in favor of its induration. Regarding the morphological state of the eyeball layers, we can say that the choroid looks unchanged. Such a phenomenon as the formation of multiple retinal tractions into the vitreous body is a new pathological formation that did not occur at the previous early stage. The main thing in the eye histological picture changes in comparison with the previous early period of the study, is the manifestations of active inflammation decline.

Conclusions. According to the results of a histomorphological study, in a rabbit with induced non-infectious anterior and intermediate uveitis normalization of the ocular surface temperature occurs in the phase of proliferation and completion of the inflammatory process.

KEY WORDS: uveitis; objectivization of inflammation assessment; ocular surface temperature; histomorphological condition.

Отримано 21.10.2020 